\title{
PREVENTIVE RESTRUCTURING, FINANCIAL DISTRESS AND VIABILITY OF THE COMPANIES
}

https://doi.org/10.47743/jopafl-2021-21-07

\author{
Tudor Andrei RĂDULESCU \\ Alexandru Ioan Cuza University of Iaşi, Faculty of Economics and Business \\ Administration \\ Iaşi, Romania \\ avocat_tudorradulescu@yahoo.ro \\ Daniela MARDIROS \\ Alexandru Ioan Cuza University of Iaşi, Faculty of Economics and Business \\ Administration \\ Iaşi, Romania \\ Cosmin DARIESCU \\ Alexandru Ioan Cuza University of Iaşi, Faculty of Law \\ Iaşi, Romania
}

\begin{abstract}
The need to restructure businesses has become a constant reality in the international economic landscape and hence the constant concern of the European legislature to harmonize the relevant legislation in the Member States. In order to harmonize the legislation, it is necessary to establish the common benchmark that will underpin the legislation of the EU countries. Defining the methods of restructuring, defining the financial difficulty and the ways of assessing the viability of companies are starting points in this approach.
\end{abstract}

Keywords: preventive restructuring, financial distress, viability

This Article was presented as a paper at the $13^{\text {th }}$ edition of the Annual International Conference Globalization and Higher Education in Economics and Business Administration (GEBA 2021), which was held at the Alexandru Ioan Cuza University, Faculty of Economics and Business Administration in Iasi, Romania from the $21^{\text {st }}$ to $23^{\text {rd }}$ of October 2021.

\section{Introduction}

For the purposes of the Directive on Preventive Restructuring and Insolvency (DPRI) - restructuring is defined as "means measures aimed at restructuring the debtor's business that include changing the composition, conditions or structure of a debtor's assets and liabilities or any other part of the debtor's capital structure, such as sales of assets or parts of the business and, where so provided under national law, the sale of the business as a going concern, as well as any necessary operational changes, or a combination of those elements”. Restructuring is a formal procedure that aims to rehabilitate a company with financial or economic problems through financial measures accompanied by operational changes (Danovi et al., 2008). Operational reorganization involves the sale of goods or the 
whole business "as a going concern" (Eidenmuller, 2017), as it may include the sale of non-productive machinery accompanied by changes in the labor force. Financial restructuring involves addressing debt by postponing the payments, canceling debt, obtaining new financing and swapping debt into equity - changing the structure of the company's capital (McCarthey, 2019). Both the reorganization and the restructuring aim to rehabilitate the company so that it can continue its activity while saving jobs. The second Recital of DPRI emphasize the importance of saving business "Restructuring should enable debtors in financial difficulties to continue business, in whole or in part, by changing the composition, conditions or structure of their assets and their liabilities or any other part of their capital structure - including by sales of assets or parts of the business or, where so provided under national law, the business as a whole - as well as by carrying out operational changes. Unless otherwise specifically provided for by national law, operational changes, such as the termination or amendment of contracts or the sale or other disposal of assets, should comply with the general requirements that are provided for under national law for such measures, in particular civil law and labor law rules. Any debt-toequity swaps should also comply with safeguards provided for by national law. Preventive restructuring frameworks should, above all, enable debtors to restructure effectively at an early stage and to avoid insolvency, thus limiting the unnecessary liquidation of viable enterprises. Those frameworks should help to prevent job losses and the loss of know-how and skills and maximize the total value to creditors - in comparison to what they would receive in the event of the liquidation of the enterprise's assets or in the event of the nextbest-alternative scenario in the absence of a plan - as well as to owners and the economy as a whole".

According to the art. 1(1)(a) of the Directive (EU) 2019/1023 of the European Parliament and of the Council "preventive restructuring frameworks available for debtors in financial difficulties when there is a likelihood of insolvency, with a view to preventing the insolvency and ensuring the viability of the debtor." It can be stated that both, the restructuring procedure and the reorganization procedure, pursue essentially identical purposes using essentially identical measures. The fundamental difference between them is represented by the circumstances in which each of these procedures is used: the restructuring procedure assumes that the debtor is not insolvent but is in a difficult situation and therefore has greater chances of rehabilitation, while the reorganization means the fact that the debtor is already insolvent. Reorganization is an entirely formal and collective procedure, while the restructuring of the company can be carried out entirely out of court or with minimal legal input and without the participation of all creditors, although there are authors who believe that restructuring should also be collective.

As a novelty, the Directive encourages preventive restructuring with little or no involvement of administrative or judicial authorities, favoring contractual / enhanced or hybrid arrangements / agreements. Last but not least, the Directive (Garrido, 2012) is intended to be a benchmark for the harmonization of legislation on preventive restructuring in the European Union. Purely contractual restructurings, enhanced and hybrid restructuring procedures are, in many cases, an effective alternative to purely formal insolvency proceedings. Regarding the rehabilitation of companies in difficulty but viable, the Directive refers to enhanced and hybrid restructurings, procedures that can be regulated and are not entirely extrajudicial or judicial, and the failure of the restructuring does not 
remove the possibility for the debtor to try a reorganization. (formal) before being forced to declare insolvency.

There is a lot of confusion in understanding the concepts of restructuring and reorganization. In fact, many legislative systems lack a clear demarcation between these procedures: starting from purely contractual agreements, going through extrajudicial restructuring - but with formal components, following the (purely) formal reorganization and ending with insolvency. (Fig.1).

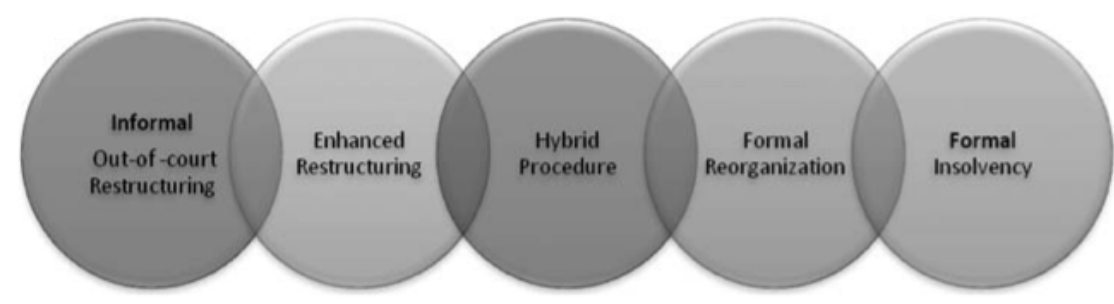

Fig.nr.1 - Rehabilitation procedures of companies (Source: World Bank)

\section{Definition of financial distress}

"Financial distress is an emerging field steeped in confusion and complexity. Some of the confusion can be resolved by understanding the diverse nature of financial distress; it is not synonymous with corporate death. Firms in distress face a variety of situations having very different effects on their values and claimholders” (Wruck, 1990)

One of the first definitions of financial distress issued by Fitzpatrick in 1932 assumes that financial distress can be considered when the company can not pay its debt at maturity. (Michalkova, 2018) There were since many attemts to define the financial difficulty; majority of them based on different symptoms: negative cash flow (Whitaker, 1999), unsecured bond (Beaver, 1966) value of debt less than value of the assets (Purnanandam, 2005) etc.

"A debtor is only in financial difficulty when he is either cash-flow or insolvent balance sheet but the company is viable. In such circumstances, the business has a higher value if it continues to operate than if it is sold in pieces or liquidated. Instead, a debtor is considered to be bankrupt when his business is not viable - that is, his assets would be worth more if they were sold in pieces than if the business continued to opérate (Mokal, 2005; Sarra, 2003).

Article 6 (2) of the Romanian law project for the transposition of the Directive accumulates some of these symptoms and states that a debtor is in financial difficulty in the following situations:

a) the turnover decreased by at least $20 \%$ in the last six months compared to the same period of the previous year and recorded a negative operating result;

b) the net current asset is negative;

c) any occurred circumstance that may reasonably lead, in the next six months, to one of the results provided in let. a) or b). 


\section{The need to develop criteria to establish the viability of enterprises}

Assessment of the viability of a company is a difficult task and the results will always be hypothetical. However, it is important that before opening a restructuring procedure to assess with the help of an experienced expert whether the company is viable or non-viable. For example, if the company produces a good that is no longer demanded on the market then the company has no chance of recovery if it is based on the same business idea. The problem is that not all cases are so simple, and the wrong choices have significant costs (Franks, 2005). Establishing the viability of a company can be a long and expensive process, for this reason it would be helpful to be provided only one test, well specified, for all companies in difficulty which asking to enter the restructuring procedures. The test must filter viable firms, and non-viable firms must undergo the liquidation procedure. It should be borne in mind that, as shown by statistical studies, 17 most companies in difficulty end up becoming insolvent and going into liquidation. For example, the liquidation rate in the second quarter of 2020 in France was about 74.62\%, in the United Kingdom in the same period was 88\%, in Spain in 2015 about 90\%, and in Germany 84\%, although all these countries have legislation that contains well-codified restructuring procedures (NIS).

In the Directive, Article 4 on the "Availability of preventive restructuring frameworks" there are mentioned three limitations: the debtor has been sanctioned for various accounting irregularities and is not allowed to access the preventive restructuring frameworks, the debtor does not pass the viability test, the debtor has also accessed that procedure and does not fall within the period in which he can access it again. The conclusion is that the restructuring procedures must be applied very carefully, after a strict assessment of the viability of the company in difficulty, according to well-established criteria and simple to apply, which does not require additional time and costs, otherwise there is a risk of occurrence two undesirable situations: either a viable company is subject to liquidation procedures, or a non-viable company is subject to restructuring - in both situations the losses will be significant and diverse (money, know-how, etc.). The role of restructuring procedures is practically to separate viable companies, which need to be restructured, including by selling "as a going concern”, from non-viable companies that will have to be liquidated as efficiently as possible (Eidenmuller, 2017).

Differentiating viable from non-viable enterprises is essential in trying to rehabilitate companies in difficulty. In order to benefit from the restructuring procedures, the company must be viable and more valuable if it continues its activity "as a going concern" than if it is sold in pieces in the liquidation procedure, and then it is considered that the company must be liquidated. This separation should be done individually for each company, which would involve a lot of time and very high costs. The role of the authorities is mainly to ensure an optimal legislative framework so as to encourage both debtors and especially creditors to choose to participate in the rehabilitation process of companies. The assessment of the viability of companies must be done primarily by creditors who have the necessary expertise to estimate whether a company is viable or not. Creditors have an important role in rehabilitating companies: by not resorting to forced executions of the debtor in difficulty or the liquidation procedure and by participating in negotiations with the desire to find the best solutions to help the company. Debtors must pay attention to early warning signs and initiate early restructuring procedures, prepared a well-structured 
restructuring plan, taking into account the most appropriate measures to save the company (capital increase, debt rescheduling, etc.).

\section{References}

1. Danovi, A., Magno, F., Dossena, G., 2018, Pursuing Firm Economic Sustainability through Debt Restructuring Agreements in Italy: An Empirical Analysis - Sustainability, 10(12), p. 4830. https://doi.org/10.3390/su10124830

2. Eidenmuller, H., 2018, Contracting for a European Insolvency Regime, Eur Bus Org L Rev, pp. 273-281. https://doi.org/10.1007/s40804-017-0067-1

3. Franks, J.R., Lóránth, G., 2005, A Study of Inefficient Going Concerns in Bankruptcy, CEPR Discussion Papers 5035.

4. Garrido, J.M., 2012, Out-of-Court Debt Restructuring, International Bank for Reconstruction and Development / International Development Association or The World Bank, Washington DC, p. 1.

5. McCarthey, J., 2019, Something Old, Something New? The Potential Impact of the EU Preventive Restructuring Directive through an Irish Case Study, International Corporate Rescue, 16(6): pp. 1-2.

6. Mokal, R.J., 2005, Corporate Insolvency Law: Theory and Application, OUP, pp. 62-67. https://ssrn.com/abstract $=701402$

7. NIS, 2021, National Insolvency Statistics: https://www.insol-europe.org/technical-content/nationalinsolvency-statistics (accesat 28 iulie 2021).

8. Sarra, J., 2003, The Existing Regime for Restructuring Insolvent Corporation, (University of Toronto Press), p. 52.

9. Tirado, I., 2017, Out of Court Debt Restructuring in Spain a Modernised Framework https://www.law.ox.ac.uk/sites/files/oxlaw/tirado_modernised_framework.pdf (accesat 28 iulie 2021).

10. Wruck, K., 1990, Financial distress, reorganization, and organizational efficiency, Journal of Financial

Economics, 27, pp. 419-444. https://doi.org/10.1016/0304-405X(90)90063-6 